\title{
MODIFIKASI PERMAINAN SEPAKBOLA BAGI SISWA SMA PENDERITA ASMA
}

\section{MODIFICATION OF SOCCER GAME FOR SENIOR-HIGH-SCHOOL-STUDENTS ASTHMA SUFFERERS}

\author{
Antonius Tri Wibowo, Wara Kushartanti \\ SMA Kolese De Britto Yogyakarta, Universitas Negeri Yogyakarta \\ smile.antonius@yahoo.com,wkushartanti@yahoo.com
}

\begin{abstract}
Abstrak
Penelitian ini bertujuan untuk menghasilkan modifikasi permainan sepakbola bagi siswa SMA penderita asma. Modifikasi permainan sepakbola diharapkan dapat digunakan oleh guru olahraga dalam pembelajaran di sekolah-sekolah yang memiliki siswa berpenyakit asma dan menjadi alternatif bagi siswa SMA yang menderita penyakit asma yang tertarik untuk bermain sepakbola. Penelitian pengembangan ini dilakukan dengan mengadaptasi langkah-langkah penelitian pengembangan menurut Borg \& Gall (1983, p.775) sebagai berikut: (1) pengumpulan informasi di lapangan, (2) melakukan analisis terhadap informasi yang telah dikumpulkan, (3) mengembangkan produk awal (draf awal), (4) validasi ahli dan revisi, (5) uji coba lapangan skala kecil dan revisi, (6) uji coba lapangan skala besar dan revisi dan (7) pembuatan produk final. Uji coba skala kecil dilakukan terhadap siswa SMA Kolese De Britto kelas X dan kelas XI yang menderita sakit asma sebanyak 13 siswa. Uji coba skala besar dilakukan di tempat yang sama dengan jumlah siswa 13 siswa yang berbeda pada saat skala kecil yang menderita asma. Hasil penelitian yaitu berupa modifikasi permainan sepakbola bagi siswa SMA penderita asma dengan perubahan ukuran lapangan, jumlah gawang disertai bentuk gawang, ukuran bola, jumlah pemain dan aturan bermain. Dari hasil penilaian para ahli, dapat ditarik kesimpulan bahwa modifikasi permainan sepakbola bagi siswa SMA penderita asma sangat baik dan efektif sebagai sarana alternatif olahraga bagi penderita asma yang ingin bermain sepakbola dan sebagai terapi asma.
\end{abstract}

Kata kunci: Permainan Sepakbola, Asma

\begin{abstract}
The main aims of this study are to create a modified soccer games for Atsmatic highschool students. The modified game hopefully can be an alternative way for sport teacher to teach soccer for Asthmatic students and make the student interested in playing it. This study was research and development type by adapting Borg \& Gall's (1983: 775) procedur of $R \& D$ research as follows: (1) data collection, (2) data analysis, (3) first draft product development, (4) expert validation and revision, (5) small scale product testing and revision, (6) large scale product testing and revision, and (7) final product development. Small scale product testing was done in Kolese De Britto Highschool, with 13 asthmatic students, class $X$ and XI. The results of the study is a modul of modified soccer for asthmatic Highschool Students. From the expert judgement, it can be seen that the modified soccer game is good and effective for atsmatic students who want to paly soccer and can be used as theraphy. The modified game can be an alternative way for sport teacher to teach soccer for asthmatic students and make the student interested in playing it.
\end{abstract}

Keywords: soccer, asthma. 


\section{Pendahuluan}

Menurut World Health Organitation (WHO) asma merupakan penyakit kronik ditandai dengan serangan sesak nafas dan mengi secara berulang, tingkat keparahan dan frekuensinya berbeda-beda antara satu individu dan individu lainnya. Nelson (1996, p.775) mendefinisikan asma sebagai kumpulan tanda dan gejala wheezing (mengi) dan atau batuk dengan karakteristik sebagai berikut: timbul secara episodik dan atau kronis, cenderung pada malam hari/dini hari (noctural), musiman, adanya faktor pencetus diantaranya aktivitas fisik dan bersifat reversible baik secara spontan maupun dengan penyumbatan, serta adanya riwayat asma atau atopi lain pada pasien/keluarga, sedangkan sebab-sebab lain sudah disingkirkan.

Siapakah manusia di dalam kehidupan ini jika ditanya, maukah dalam kehidupannya mengalami ketidaksempurnaan? pasti jawabannya tidak, memang berat jika di dalam kehidupan manusia mengalami ketidaksempurnaan dalam kehidupan, baik ketidaksempurnaan keluarga, kesehatan, percintaan, dan pekerjaan. Sebagai manusia beragama tentunya percaya manusia diciptakan Tuhan dengan sempurna karena manusia merupakan citra Tuhan sendiri tetapi kenyataannya banyak manusia yang mengalami ketidaksempurnaan dalam kehidupannya karena itu adalah berkat yang diberikan Tuhan. Setiap situasi ketidaksempurnaan yang manusia alami akan dirasakan ketidaknyamanan dalam kehidupan manusia itu.

Demikian juga dalam ketidaksempurnaan kesehatan, manusia akan terganggu kehidupannya, seperti ingin beraktivitas karena adanya ketidaksempurnaan fisik jadi kesulitan dalam beraktivitas, ingin bekerja tetapi tidak bisa maksimal sehingga manusia tidak dapat berkembang apalagi untuk bekerja keras maka akan berpengaruh pada fisik, pikiran sehingga akan menyebabkan kambuhnya penyakit yang sudah dimiliki. Manusia ingin berolahraga tetapi takut dan was-was kalau sakitnya kambuh sehingga menyebabkan serba salah sehingga manusia yang memiliki riwayat penyakit akan menjadi stres dan tertekan dan akan menyebabkan penyakitnya tambah parah. Ada berbagai macam penyakit yang bisa mempengaruhi kinerja manusia dalam beraktifitas salah satunya adalah penyakit asma.

Berdasarkan data World Health Organization (WHO), jumlah penderita asma di dunia diperkirakan terus bertambah sebanyak
180.000 orang setiap tahunnya dan meningkat hingga 400.000 orang pada tahun 2005. Hasil survei di Medan, Palembang, Jakarta, Bandung, Semarang, Yogyakarta, Malang dan Denpasar menunjukkan prevalensi asma pada anak berkisar antara 3,7\%-16,4\%. Di Indonesia asma termasuk sepuluh besar penyebab kesakitan dan kematian, hal ini tergambar dari data Studi Survei Kesehatan Rumah Tangga (SKRT) di berbagai provinsi di Indonesia. SKRT pada tahun 1986 menunjukkan asma menduduki urutan kelima dari 10 penyebab kesakitan (morbiditas) bersama-sama dengan Bronkitis dan Emfisema (Prasetya, 2010, p.11). Peningkatan penderita asma pada anak disebabkan oleh kurangnya pengetahuan tentang asma dan tata laksananya.

Penyakit asma dapat mengganggu semua manusia dalam aktivitasnya dan tidak dipungkiri untuk semua orang dari anak-anak sampai orang tua pun kalau mengidap penyakit asma tentunya akan terganggu bahkan akan berpengaruh pada kinerja seseorang dalam bekerja jika itu seorang pekerja, jika seorang anak dan pelajar tentunya akan mempengaruhi prestasi belajar dan sosial si anak penderita karena akan tidak maksimal dalam semua kegiatannya. Asma yang sering kambuh akan menggangu aktivitas anak, karena takut asmanya kambuh, orang tua akan melarang anaknya untuk berolahraga ataupun kegiatan-kegiatan lainnya. Padahal untuk anak-anak sampai remaja adalah masa berkembang sehingga bagus untuk perkembangan si penderita untuk mengembangkan nilai sosial dalam kelompoknya. Masa anakanak dan remaja adalah masa yang penting untuk dapat tumbuh dan berkembang dengan baik, batasan-batasan dan larangan yang diberikan oleh orang tua kepada anaknya yang menderita asma terkadang berlebihan, sehingga anak menjadi terbatas kegiatan dan aktivitasnya yang justru dapat mengganggu tumbuh kembang anak dengan normal. Sikap ketakutan dan over protektif orang tua terhadap anaknya yang menderita asma akan menyebabkan tingkat stress pada anak tinggi dan akan sangat berdampak negatif pada perkembangan anak, karena anak akan terkekang sehingga tidak bebas beraktifitas, perlu dipahami ini sebagai salah satu penyebab timbulnya asma yang berkaitan dengan psikologi anak.

Banyak persepsi yang berkembang di kalangan masyarakat bahwa aktivitas jasmani (olahraga) akan mengakibatkan kambuhnya penyakit asma, sehingga orang tua yang anaknya adalah penderita asma akan melarang dengan 
keras jika anaknya akan melakukan kegiatankegiatan yang berhubungan dengan aktivitas jasmani (olahraga). Semua pandangan tentang aktivitas jasmani akan menjadi penyebab kambuhnya penderita asma berkembang meluas dari masyarakat dan secara turun temurun dari orang tua kepada anaknya dan sampai seterusnya, sehingga anak yang memiliki penyakit asma tentunya akan terdoktrin di pikirannya bahwa aktivitas jasmani akan menyebabkan asmanya kambuh dan semua itu akan membuat anak ketakutan untuk melakukan aktivitas jasmani (olahraga) yang digemarinya sehingga akan berdampak pada kebugaran tubuh anak penderita asma tersebut.

Munculnya berbagai sistem trasportasi dan teknologi mesin pabrik pada kenyataannya telah membawa lingkungan cenderung pada kondisi yang kurang baik. Meningkatnya polusi udara serta berbagai kenyamanan yang pada dasarnya memanjakan manusia dalam dimensi fisiknya, ternyata pada akhirnya semakin menyudutkan manusia pada situasi yang kurang menguntungkan dari segi kesehatan, terlebih bagi penderita asma. Diketahui bersama panderita asma akan sangat sensitif pada situasi di mana kualitas udara tidak begitu bagus. Secara klinis, penyakit asma belum bisa disembuhkan dengan hanya mengandalkan medicine treatment, namun lebih jauh harus diimbangi dengan perila$\mathrm{ku}$ serta kondisi yang relatif kondusif dalam upaya penyembuhannya. Akitivitas olahraga yang rutin dengan bentuk olahraga yang disesuaikan dengan karakter asma serta kondisi lingkungan, terutamanya keadaan udara sangat menentukan keberhasilan upaya penyembuhan bagi penderita asma.

Pengobatan asma bertujuan menjadikan keadaan asma terkontrol. Asma yang terkontrol adalah keadaan asma yang tanpa gejala, tidak ada gangguan pada saat tidur, tidak ada serangan asma di malam hari, tidak ada keterbatasan aktivitas, tidak ada pemakaian obat-obatan, dan tidak ada kunjungan ke unit gawat darurat. Keadaan ini bisa didapat apabila asma diberikan pengobatan yang optimal dan akurat.

Penyakit asma adalah penyakit tidak bisa disembuhkan, tetapi dapat dikontrol dan dikurangi sedemikian rupa sehingga penderita dapat hidup seperti orang normal. Serangan asma timbul bila ada faktor pencetus. Faktor pencetus pada penderita asma biasanya bersifat individu atau spesifik, artinya individu tertentu hanya terkena serangan asma bila tercetus oleh faktor penyebab tertentu. Pada beberapa pende- rita kadang-kadang faktor pencetusnya tidak terdeteksi, hal ini mungkin karena beberapa faktor pencetus berperan secara bersamaan untuk menimbulkan serangan asma. Pencegahan serangan asma yang utama adalah menghindari faktor pencetus, tetapi hal ini tidaklah selalu mudah karena beberapa faktor pencetus seperti perubahan cuaca, stres dan infeksi saluran napas kadang-kadang sulit dihindari. Apabila terjadi serangan asma, hendaklah diatasi dengan segera karena serangan yang berkepanjangan dapat menimbulkan kelainan yang menetap pada saluran napas, keadaan ini dapat mengakibatkan derajat penyakit menjadi lebih berat. Apabila penataan asma dilakukan dengan baik, keadaan asma terkontrol dapat dicapai, dengan demikian penderita asma dapat hidup seperti orang normal yang berarti terjadi peningkatan kualitas hidup penderita asma.

Peneliti melihat siswa atau pelajar di tempat peneliti mengajar, siswa yang memiliki penyakit asma akan mengalami kesulitan dalam aktivitas belajarnya jika terlalu banyak tugas sehingga tingkat ketegangan meninggi dan akan berdampak pada tingkat stress siswa, ini juga terjadi pada waktu mengikuti pelajaran pendidikan jasmani dan kesehatan dalam aktivitas yang berat. Siswa yang memiliki penyakit asma akan mengalami kesulitan dalam mengikuti pelajaran pendidikan jasmani dan kesehatan di sekolah, sehingga akan berpengaruh pada penilaian terhadap siswa yang memiliki penyakit asma tersebut. Bagi orangtua siswa yang memiliki anak yang berpenyakit asma tentunya akan selalu khawatir pada keadaan anaknya kalau dalam proses belajarnya di sekolah anaknya mengalami kambuh.

Pengalaman beberapa tahun yang lalu sejak peneliti menjadi siswa sekolah dan sekarang menjadi seorang pendidik di sekolah swasta di Yogyakarta yang siswanya laki-laki semua. Seorang siswa yang menderita sakit sehingga izin tidak mengikuti pelajaran olahraga akan mendapat ejekan, termasuk penderita asma sering menjadi ejekan dimanapun penderita berada, di dalam keluarga dan lingkungan bermain sampai di lingkungan sekolah pun anak penderita asma mendapat perlakuan guru pendidikan jasmani dan kesehatan sering tidak adil. Anak penderita asma dianggap anak yang lemah, sehingga sering dan bahkan tidak diizinkan mengikuti pelajaran pendidikan jasmani dikarenakan jika dalam beraktivitas fisik akan kambuh. 
Sekilas penderita asma dimanjakan karena saat penderita asma mengalami kambuh asmanya sewaktu melakukan pelajaran olahraga siswa yang sakit asma langsung disuruh istirahat dan bahkan sebelum melakukan pelajaran pendidikan jasmani dan kesehatan siswa yang sakit asma boleh tidak mengikuti pelajaran. Di sekolah terjadi diskriminasi pada penderita asma yang sebenarnya mampu dan memiliki kemampuan untuk berprestasi olahraga tetapi karena guru olahraganya khawatir melihat nanti bisa terjadi kambuh asmanya sehingga penderita tidak diikutkan dalam permainan bahkan dalam tim olahraga sekolah. Padahal dengan perlakuan seperti di atas justru sebaliknya penderita asma akan semakin menurun derajat kesehatannya dikarenakan penderita tidak pernah melakukan kegiatan olahraga, selain itu secara psikologi siswa yang menderita asma akan menurun kepercayaan dirinya dengan perlakukan negatif terhadap penderita asma.

Seiring kemajuan ilmu pengetahuan dan teknologi para pakar olahraga berusaha merubah paradigma tentang pendidikan jasmani, bahwa pendidikan jasmani dan kesehatan adalah suatu bagian dari pendidikan keseluruhan yang mengutamakan aktivitas jasmani dan pembinaan hidup sehat untuk pertumbuhan dan perkembangan jasmani, mental, sosial, dan emosional yang serasi selaras dan seimbang (Depdikbud 1997, p.1). Sehingga perlu dipahami bahwa dengan berakitivitas jasmani tidak akan menimbulkan kambuhnya penyakit asma jika aktivitas jasmani itu dilakukan dengan benar dan sesuai dengan porsi penderita asma.

Sepakbola merupakan olahraga yang sangat terkenal dan merakyat sehingga di segala lini kehidupan baik di masyarakat kecil ataupun masyarakat menengah bahkan kalangan atas, permainan sepakbola adalah olahraga yang sering menjadi bagian kalangan itu. Lingkungan pendidikan termasuk juga mengidolakan permainan sepakbola, ini terbukti dari banyaknya siswa yang suka dan tertarik untuk bermain sepakbola pada saat materi sepakbola dalam pelajaran pendidikan jasmani dan kesehatan. Di luar jam pelajaran yaitu waktu istirahat siswa-siswa banyak yang melakukan permainan sepakbola yang dilakukan di lapangan outdor ataupun lapangan indoor. Namun permainan sepakbola ini bagi penderita asma adalah sesuatu yang menakutkan karena siswa-siswa yang mempunyai penyakit asma terdoktrin dari orang tuanya bahwa aktivitas olahraga akan menyebabkan timbulnya asma dan persepsi itu diturunkan secara turun temurun oleh orang tua kepada anak. Olahraga memang sebagai salah satu penyebab kambuhnya penyakit asma itu persepsi yang benar, olahraga yang dimaksud adalah olahraga yang berat dan berdurasi lama yang akan menimbulkan kambuhnya penyakit asma.

Survei yang dilakukan peneliti dengan pendataan menggunakan angket setiap tahun pelajaran pada tahun pelajaran 2011-2012 dalam proses belajar mengajar di sekolah SMA De Britto Yogyakarta yang notabenenya adalah tempat mengajar peneliti dengan semua siswanya laki-laki berjumlah 750 siswa. Di sekolah SMA De Britto ditemukan dari 7 kelas yang merupakan kelas $\mathrm{X}$ yang diajar setiap kelasnya terdiri dari 35 siswa dan setiap kelas menyumbangkan penderita asma 2-3 siswa, data itu belum termasuk siswa yang dari kelas XI dan kelas XII dan peneliti mendata 70 siswa yang menderita asma dan sebagian besar adalah asma ringan. Sekolah memiliki fasilitas lapangan sepakbola yang memadai sehingga mendorong siswa untuk mengidolakan sepakbola, siswa yang memiliki penyakit asma adalah penggemar olahraga, khususnya sepakbola, ini terlihat pada saat pelajaran olahraga rekreasi bebas setelah selesai materi selalu diadakan permainan sepakbola. Siswa yang memiliki asma selalu ikut bermain sepakbola tetapi terkadang tidak sampai selesai karena mengeluh mengalami gangguan dengan asmanya sehingga harus istirahat padahal masih sangat berkeinginan untuk bermain tetapi peneliti melarangnya untuk melanjutkan bermain sepakbola karena berkaitan dengan asmanya.

Asma yang sering kambuh akan menggangu aktivitas anak, karena takut asmanya kambuh, orang tua akan melarang anaknya untuk berolahraga khususnya sepakbola ataupun kegiatan-kegiatan lainnya. Olahraga sepakbola merupakan olahraga yang bisa dijadikan media dalam bersosialisasi antarpemain, jadi untuk anak-anak yang sedang berada dalam masa perkembangan sangat bagus untuk perkembangan penderita untuk mengembangkan nilai sosial dalam kelompoknya. Masa anak-anak dan remaja adalah masa yang penting untuk dapat tumbuh dan berkembang dengan baik. Batasanbatasan dan larangan yang diberikan oleh orang tua kepada anaknya yang menderita asma terkadang berlebihan. Anak menjadi terbatas kegiatannya dan aktivitasnya yang justru dapat mengganggu tumbuh kembang anak dengan normal. Sikap ketakutan dan over protektif orang tua terhadap anak yang menderita asma 
akan menyebabkan tingkat stres pada anak dan anak yang menderita asma akan sangat menderita, perlu dipahami bahwa sebagai salah satu penyebab timbulnya asma adalah yang berkaitan dengan psikologi anak.

\section{Metode}

\section{Waktu dan Tempat Penelitian}

Penelitian dan pengembangan ini dilakukan mulai bulan Februari sampai bulan Agustus 2013. Uji coba lapangan skala kecil dilakukan di SMA Kolese De Britto pada hari Rabu tanggal 13 Mei 2013 dengan subjek berjumlah 13 siswa yang memiliki asma. Setelah mendapat perbaikan produk modifikasi permainan sepakbola kemudian uji coba skala besar ini dilakukan pada hari Rabu tanggal 29 Mei 2013 di SMA Kolese De Britto dengan jumlah subjek 13 siswa penderita asma yang berbeda dari subjek uji coba skala kecil.

\section{Target/Subjek Penelitian}

Subjek coba dalam penelitian pengembangan ini adalah siswa SMA penderita asma kategori asma ringan berdasarkan pengecekan gejala klinis. Uji coba lapangan skala kecil dilakukan terhadap siswa SMA Kolese De Britto berjumlah 13 siswa. Sementara uji coba lapangan skala besar dilakukan terhadap siswa SMA Kolese De Britto berjumlah 13 siswa.

\section{Model Pengembangan}

Penelitian yang dilakukan menggunakan metode penelitian dan pengembangan atau sering disebut (research and development). Borg dan Gall (1983, p.772) menyatakan penelitian dan pengembangan merupakan metode penelitian untuk menghasilkan produk-produk pendidikan, baik produk yang berupa objek material seperti buku teks, dan film pengajaran. Produk yang berupa proses dan prosedur yang ditemukan seperti metode mengajar atau metode mengorganisir pengajaran.

Penelitian pengembangan dilakukan untuk menghasilkan sebuah modifikasi permainan sepakbola bagi siswa SMA penderita asma ke dalam buku panduan berjudul Asmaball (modifikasi permainan sepakbola bagi penderita asma). Pengembangan dilakukan berdasarkan karakteristik olahraga untuk asma dan kurikulum sekolah SMA sehingga modifikasi ini bisa menjadi alternatif bagi penderita asma yang tertarik untuk bermain sepakbola.

\section{Prosedur Penelitian dan Pengembangan}

Prosedur pengembangan dalam penelitian ini adalah sesuai dengan langkah-langkah penelitian menurut Borg dan Gall (1983). Penelitian dan pengembangan dilakukan melalui beberapa langkah. Menurut Borg dan Gall (1983, p.222) dalam melakukan penelitian pengembangan, ada beberapa langkah yang harus ditempuh, langkah-langkah yang harus ditempuh tersebut, dapat digambarkan sebagai berikut, (1) studi pendahuluan dan pengumpulan data (kajian kepustakaan, pengamatan kelas, membuat kerangka kerja penelitian), (2) perencanaan (merumuskan tujuan penelitian, memperkirakan dana dan waktu yang diperlukan, prosedur kerja penelitian, dan berbagai bentuk partisipasi kegiatan selama kegiatan penelitian), (3) mengembangkan produk awal (perancangan draft awal produk), (4) uji coba awal (mencobakan draft produk ke wilayah dan subjek yang terbatas), (5) revisi untuk menyusun produk utama (revisi produk berdasarkan hasil uji coba awal), (6) uji coba lapangan utama (uji coba terhadap produk hasil revisi ke wilayah dan subjek yang lebih luas), (7) revisi untuk menyusun produk operasional, (8) uji coba produk operasional (uji efektivitas produk), (9) revisi produk final, dan (10) diseminasi dan implementasi produk hasil pengembangan.

Langkah-langkah tersebut diadaptasi menjadi tujuh (7) rancangan prosedur penelitian pengembangan berikut ini:

\section{Pengumpulan Informasi di Lapangan}

Peneliti adalah guru olahraga di SMA De Britto selalu mendapat ungkapan keluhan siswa SMA Kolese De Britto penderita asma yang melakukan permainan sepakbola konvensional dan mengalami kambuh pada saat bermain sepakbola. Peneliti kemudian mencari informasi lebih dalam terhadap siswa-siswa penderita asma berapa lama mengalami asma, berapa kali mengalami kekambuhan, berapa lama siswa kembali sehat setelah asma, sampai apakah siswa memiliki orang tua penderita asma. Selain itu peneliti mencari informasi-informasi mengenai asma dari beberapa buku mengenai olahraga untuk penderita asma dan permasalahan-permasalahan yang terjadi sekitar asma. Tidak berhenti di situ saja peneliti selalu mengamati siswa yang memiliki asma pada saat bermain sepakbola bersama temannya yang tidak menderita asma di lapangan. Berdasarkan informasi yang didapat peneliti kemudian menyelidiki perma- 
salahan-permasalahan yang dihadapi penderita asma yang mengalami kesulitan atau kekambuhan pada saat bermain sepakbola konvensional, sepakbola yang bagaimana dimainkan oleh penderita asma di sekolah dan sepakbola yang bagaimana yang aman untuk penderita asma.

\section{Melakukan Analisis Terhadap Informasi yang Telah Dikumpulkan.}

Analisis dilakukan terhadap data hasil studi pustaka dan wawancara. Analisis terhadap hasil studi pustaka digunakan untuk pemantapan dalam memfokuskan massalah yang dikaji melalui beberapa sumber buku dan informasi dari beberapa teman kedokteran yang tentunya lebih berkompetensi dalam hal asma. Sementara analisis terhadap hasil wawancara terhadap siswa dan guru olahraga dilakukan untuk mengetahui kebenaran asumsi peneliti dari kondisi nyata di lapangan mengenai permasalahan-permasalahan yang dihadapi penderita asma dalam melakukan permainan sepakbola konvensional.

\section{Mengembangkan Produk Awal (Draf Model)}

Setelah proses analisis, peneliti mulai membuat suatu produk guna membantu guru dan siswa untuk mengatasi permasalahan yang ditemui dalam pelaksanaan pembelajaran aktivitas jasmani khususnya pada materi permainan sepakbola. Dalam mengembangkan produk awal beberapa hal yang dilakukan sebagai berikut: Dalam mengembangkan produk awal beberapa langkah sebagai berikut: (a) Analisis tujuan dan karakteristik pengembangan olahraga sepakbola bagi penderita asma; (b) Analisis gerakan dalam sepakbola yang tidak menyebabkan kambuhnya penyakit asma; (c) Mengembangkan modifikasi permainan sepakbola bagi penderita asma.

Berdasarkan langkah tersebut peneliti mengembangkan produk modifikasi permainan sepakbola dengan merubah ukuran lapangan sepakbola, jumlah gawang dan ukuran gawang, jumlah pemain, waktu permainan dan peraturan-peraturan permainan.

\section{Validasi Ahli dan Revisi}

Sebelum dilakukan uji coba skala kecil dilakukan validasi dari ahli terhadap draf modifikasi permainan sepakbola bagi siswa SMA penderita asma (ASMABALL). Validasi ini dilakukan oleh pakar yang di terdiri dari 2 ahli dan 1 guru olahraga. (1) Pakar bidang permainan Sepakbola yaitu Drs. Herwin, M.Pd. (2) Pakar kesehatan yaitu dr. Novita Intan Arovah, MPH. (3) Guru olahraga yaitu Christoporus Danang Wahyu, S.Pd. Validitas ini tujuannya untuk mendapatkan pengesahan dan reabilitas terhadap model modifikasi permainan sepakbola bagi penderita asma serta mendapat masukan dari para pakar dari draf produk yang dihasilkan. Pada proses validasi, para ahli materi menilai dan memberi masukan terhadap produk awal. Berdasarkan hal tersebut, dilakukan revisi terhadap produk awal. Proses revisi ini terus dilakukan sampai produk awal mencapai batas nilai tertentu yang telah ditetapkan, yang menunjukkan bahwa produk awal tersebut valid dan layak diujicobakan.

\section{Uji Coba Lapangan Skala Kecil dan Revisi}

Uji coba lapangan skala kecil dilakukan di SMA Kolese De Britto pada hari Rabu tanggal 13 Mei 2013 dengan subjek berjumlah 13 siswa yang memiliki asma. Uji coba skala kecil dilakukan dan didokumentasikan dalam bentuk Video Compact Disc (VCD), yang kemudian di observasi oleh ahli sepakbola, ahli kesehatan dan guru olahraga dengan panduan observasi yang disusun oleh peneliti. Uji coba skala kecil ini peneliti menghitung gerakan anaerobik pemain dengan melakukan pencatatan menggunakan stopwatch tetapi karena jumlah penghitung hanya 7 orang sehingga pemain yang dihitung gerakan anaerobiknya hanya 7 pemain. Masukan yang diterima dari para ahli dan guru olahraga ditindaklanjuti dengan melakukan revisi produk. Masukan dari para ahli dan guru olahraga juga dipertimbangkan sebagai bahan untuk merevisi produk, selain itu yang tak kalah penting adalah masukan dari siswa-siswa yang melakukan permainan asmaball dijadikan catatan penting untuk memperbaiki produk.

\section{Uji Coba Lapangan Skala Besar dan Revisi}

Setelah mendapat perbaikan produk modifikasi permainan sepakbola kemudian uji coba skala besar ini dilakukan pada hari Rabu tanggal 29 Mei 2013 di SMA Kolese De Britto dengan jumlah subjek 13 siswa penderita asma yang berbeda dari subjek uji coba skala kecil. Proses yang dilakukan pada tahap uji coba lapangan skala besar serupa dengan proses yang dilakukan pada tahap uji coba skala kecil. Uji coba skala besar didokumentasikan dalam bentuk Video Compact Disc (VCD). Uji coba skala kecil ini peneliti menghitung gerakan anaerobik pemain dengan melakukan pencatatan menggunakan stopwatch tetapi karena jumlah penghi- 
tung hanya 10 orang sehingga pemain yang dihitung gerakan anaerobiknya hanya 10 pemain. Proses revisi produk dilakukan setelah mendapat masukan dari para ahli materi untuk menghasilkan produk final.

\section{Pembuatan Produk Final}

Setelah melalui berbagai proses revisi, dilakukan penyusunan dan pembuatan produk akhir atau produk final berupa modifikasi permainan sepakbola bagi siswa SMA penderita Asma dengan diberi nama Permainan Asmaball dan dijadikan sebuah modul atau buku.

\section{Uji Coba Produk}

\section{Desain Uji Coba.}

Desain uji coba dalam penelitian ini dilakukan sebanyak dua kali, yaitu uji coba skala kecil dan uji coba skala besar. Sebelum dilaksanakan uji coba di lapangan, peneliti membuat draf awal produk berupa modifikasi permainan sepakbola bagi penderita asma siswa SMA (asmaball). Draf awal produk divalidasi terlebih dahulu kepada para ahli/pakar permainan sepakbola dan pakar kesehatan, serta guru olahraga sebagai salah pengguna di lapangan. Pakar tersebut adalah Dosen Ilmu Keolahragaan di FIK UNY yaitu Drs. Herwin, M.Pd, dr Novita Intan Arovah, MPH dan Guru Olahraga Christoporus Danang Wahyu, S.Pd. Dalam tahap validasi para ahli/pakar dan praktisi diberikan penilaian terhadap draf modifikasi permainan sepakbola bagi penderita asma pada siswa SMA (asmaball) yang telah disusun dengan menggunakan skala nilai, sehingga akan diketahui apakah model yang disusun layak untuk diujicobakan di lapangan. Dalam tahap uji coba di lapangan peran ahli/pakar serta guru olahraga adalah mengobservasi kesesuaian dan keefektifan draf model yang telah disusun dengan kenyataan di lapangan. Akhirnya setelah uji skala luas maka akan menghasilkan sebuah model yang valid.

\section{Subjek Coba}

Subjek coba dalam penelitian ini adalah siswa SMA Kolese De Britto yang memiliki penyakit asma dengan keterangan gejala klinis yang dialami murid yang memiliki penyakit asma kemudian dikonsultasikan oleh dokter yang sekaligus pembimbing penelitian dan hasil pengecekkan gejala klinis diketahui bahwa siswa termasuk penderita asma kategori ringan. Kemudian sesuai dengan tahapan penelitian akan dilaksanakan beberapa tahapan proses pengambilan data. Dalam penelitian ini dilakukan uji coba permainan di lapangan yaitu uji coba skala kecil dan skala besar. Untuk uji coba skala kecil melibatkan 13 siswa dan skala besar melibatkan 13 siswa dan semua subjek siswa SMA Kolese De Britto yang kebetulan laki-laki semua karena memang sekolah ini khusus untuk laki-laki dengan kategori tingkat asma ringan.

\section{Jenis Data}

Jenis data yang diperoleh dalam penelitian ini adalah data kualitatif dan data kuantitatif. Data kualitatif diperoleh dari: (a) data kekurangan draf modifikasi permainan sepakbola bagi penderita asma dari ahli dan guru olahraga, (b) data masukan dari ahli dan guru olahraga terhadap draf modifikasi permainan sepakbola bagi penderita asma, (c) data hasil wawancara seberapa keefektifan dari modifikasi permainan sepakbola bagi penderita asma pada siswa. Data kuantitatifnya diperoleh dari: (a) penilaian ahli materi terhadap modifikasi permainan sepakbola bagi penderita asma, (b) penilaian guru olahraga terhadap modifikasi permainan sepakbola begi penderita asma, (c) penilaian ahli materi terhadap keefektifan modifikasi permainan sepakbola bagi penderita asma, (d) penelitan ahli materi terhadap guru pelaku uji coba, (e) penilaian siswa penderita asma terhadap modifikasi permainan sepakbola bagi penderita asma.

\section{Instrumen Pengumpulan Data}

\section{Wawancara}

Teknik pengumpulan data pertama yang digunakan yaitu teknik komunikasi langsung dengan menggunakan instrumen wawancara sebagai alat pengumpul data. Subana (Riduwan, 2007, p.29) menyatakan bahwa wawancara merupakan alat pengumpul data yang digunakan untuk memperoleh informasi langsung dari sumbernya. Wawancara digunakan untuk mengetahui hal-hal dari responden, ada beberapa faktor yang akan mempengaruhi arus informasi dalam wawancara yaitu: pewawancara, responden, pedoman wawancara, dan situasi wawancara. Pewawancara adalah petugas pengumpul informasi yang diharapkan dapat menyampaikan pertanyaan dengan jelas. Responden adalah pemberi informasi yang diharapkan dapat menjawab semua pertanyaan dengan jelas dan lengkap. Pedoman wawancara berisi tentang uraian penelitian yang biasanya dituangkan dalam bentuk pertanyaan. Situasi wawancara berhubungan dengan waktu dan tempat 
wawancara (Riduwan, 2007, p.29). Alat yang digunakan untuk merekam hasil wawancara adalah handphone.

Wawancara yang dilakukan yaitu wawancara bebas terpimpin, di mana pedoman wawancara digunakan sebagai pegangan pewawancara dalam mewawancarai responden. Pedoman wawancara tidak berbentuk seperangkat pertanyaan, namun hanya berbentuk butir-butir pertanyaan yang perlu disampaikan, yang disusun berdasarkan massalah, submassalah dan variabel penelitian. Butir-butir tersebut merupakan pegangan agar data yang dikumpulkan tidak menyimpang dari massalah yang ingin digali. Pewawancara membawa pedoman yang hanya merupakan garis besar tentang hal-hal yang ingin ditanyakan (Riduwan, 2007, p.30). Pewawancara menyusun sendiri kalimat pertanyaan tentang butir-butir tersebut yang redaksionalnya kadang berbeda, tetapi isinya sama setiap menyampaikan pertanyaan pada setiap responden.

Pewawancara harus dapat menggali keterangan-keterangan dari responden, sedangkan responden diharapkan mampu memberikan informasi yang dibutuhkan. Supaya memperoleh informasi yang tepat, objektif, dan lengkap ada urutan-urutan prosedur dalam memulai wawancara yaitu: menerangkan kegunaan dan tujuan dari penelitian, menjelaskan mengapa responden terpilih untuk diwawancarai, menjelaskan institusi yang melaksanakan penelitian, dan menerangkan bahwa wawancara tersebut merupakan sesuatu yang confidential (Nazir, 2011, p.200).

Pertanyaan yang disusun dalam pedoman wawancara disesuaikan dengan tujuan pelaksanaan wawancara yaitu untuk menggali dan massalah-massalah yang dihadapai siswa penderita asma dalam melakukan olahraga khususnya olahraga sepakbola, Butir-butir pertanyaan tersebut meliputi: (1) lama menderita asma, (2) penyebab kambuhnya asma, (3) yang dialami pada saat kambuh, (4) olahraga apa yang memacu asma, (5) keseringan kambuh asma, (6) perlakukan asma saat berolahraga, (7) olahraga refreshing bisa menjadi alternatif bagi asma.

\section{Skala Nilai (Rating Scale)}

Instrumen pengumpul data kedua yang digunakan yaitu skala nilai. Skala nilai digunakan untuk menilai kelayakan modifikasi permainan sepakbola (asmaball) yang dikembangkan sebelum pelaksanaan uji coba skala kecil, setelah para ahli menilai bahwa modifikasi sepak- bola sudah sesuai dengan unsur-unsur dalam skala nilai, modifikasi sepakbola bagi penderita asma baru dapat diujicobakan dalam uji coba skala kecil.

Di dalam skala nilai, variabel atau tujuan penelitian diklasifikasikan secara rinci menjadi gejala-gejala dengan unsur-unsurnya. Klasifikasi tersebut disusun ke bawah, sedangkan ke samping dicantumkan kategori sesuai dengan maksud/tujuan penelitian, antara lain berupa urutan kualitas data yang dikumpulkan. Kategori yang dimaksud dalam skala penilaian dari ahli dan guru olahraga adalah kategori berskala dua, yaitu setuju dan tidak setuju. Cara penggunaan skala nilai yaitu, bilamana muncul gejala atau unsur-unsur seperti yang terdapat dalam klasifikasi data, para pakar dan guru memberikan tanda cek $(\sqrt{ })$ pada kolom kategori. Apabila gejala atau unsur-unsur seperti yang terdapat dalam klasifikasi data dinyatakan setuju maka nilainya satu (1) dan apabila dinyatakan tidak setuju maka nilainya nol (0). Kemudian untuk mengetahui respon dari siswa atau penderita asma mengunakan skala empat yaitu apabila pendapat sangat setuju (SS) maka nilainya 4, apabila setuju (S) nilainya 3, apabila tidak setuju nilainya (2), apabila sangat tidak setuju nilainya (1).

Tabel 1. Kisi-kisi Klasifikasi Skala Nilai untuk

Para Pakar Sepakbola Terhadap Modifikasi

Permainan Sepakbola bagi Siswa SMA

Penderita Asma

\begin{tabular}{clc}
\hline No & \multicolumn{1}{c}{ Klasifikasi } & Item Nomor \\
\hline 1. & $\begin{array}{l}\text { Kemudahan dalam memain- } \\
\text { kan modifikasi permainan } \\
\text { sepakbola }\end{array}$ & 1 \\
2. & $\begin{array}{l}\text { Peraturan permainan mudah } \\
\text { dipahami }\end{array}$ & 2 \\
3. & $\begin{array}{l}\text { Modifikasi permainan tidak } \\
\text { menyimpang jauh dari }\end{array}$ & 3 \\
& $\begin{array}{l}\text { sepakbola sebenarnya } \\
\text { Permainan yang murah dan } \\
\text { untuk massal }\end{array}$ & 4 \\
5. Peralatan tidak berbahaya & 5 dan 6 \\
dan mudah didapat & $\begin{array}{l}\text { Olahraga bersifat refreshing } \\
\text { Modifikasi permainan tidak } \\
\text { menyalahi dari aturan FIFA }\end{array}$ & 7 \\
\hline
\end{tabular}


Tabel 2. Kisi-kisi Klasifikasi Skala Nilai untuk

Pakar Kesehatan Terhadap Modifikasi Permainan Sepakbola bagi Penderita Asma

\begin{tabular}{clc}
\hline No & \multicolumn{1}{c}{ Klasifikasi } & Item Nomor \\
\hline 1. & $\begin{array}{l}\text { Kemudahan bagi penderita } \\
\text { asma }\end{array}$ & 1 \\
2. & $\begin{array}{l}\text { Sebagai olahraga alternatif } \\
\text { bagi penderita asma } \\
\text { Olahraga refreshing bagi } \\
\text { penderita asma }\end{array}$ & 2 \\
Olahraga intermitten bagi \\
asma
\end{tabular}

Tabel 3. Kisi-kisi Klasifikasi Skala Nilai untuk Guru Olahraga Terhadap Modifikasi Permainan Sepakbola bagi Penderita Asma

\begin{tabular}{|c|c|c|}
\hline No & Klasifikasi & Item Nomor \\
\hline 1. & $\begin{array}{l}\text { Mudah bagi siswa pende- } \\
\text { rita asma }\end{array}$ & 1 \\
\hline 2. & $\begin{array}{l}\text { Sebagai media olahraga } \\
\text { bagi penderita asma }\end{array}$ & 2 \\
\hline 3. & $\begin{array}{l}\text { Modifikasi bisa diterapkan } \\
\text { dalam pembelajaran di } \\
\text { sekolah }\end{array}$ & 3 \\
\hline 4. & $\begin{array}{l}\text { Peralatan mudah didapat- } \\
\text { kan }\end{array}$ & 4 \\
\hline 5. & $\begin{array}{l}\text { Peralatan aman bagi siswa } \\
\text { asma }\end{array}$ & 5 \\
\hline 6. & Bisa dimainkan massal & 6 \\
\hline 7. & $\begin{array}{l}\text { Ukuran lapangan bisa di- } \\
\text { terapkan di sekolah }\end{array}$ & 7 \\
\hline 8 & $\begin{array}{l}\text { Waktu permainan tidak } \\
\text { terlalu lama }\end{array}$ & 8 \\
\hline
\end{tabular}

\section{Intrumen Observasi}

Teknik pengumpulan data ketiga yang digunakan yaitu teknik observasi tidak langsung dengan instrumen observasi berupa daftar cek (check list). Teknik observasi merupakan cara mengumpulkan data yang dilakukan melalui pengamatan, dengan pengamatan terdapat kemungkinan untuk mencatat hal-hal, perilaku, pertumbuhan, dan sebagainya sewaktu kejadian tersebut berlangsung (Nazir, 2011, p.175). Alat yang dipakai dalam membantu instrumen observasi yaitu menggunakan ratting scale. Ratting scale adalah sebuah instrumen yang mewajibkan pengamat untuk menetapkan subjek pada kategori dengan memberikan nomor atau angka pada kategori-kategori tersebut (Nazir, 2011, pp.181-185).

Cara mencatat observasi tidak memunyai standar tertentu, yang paling penting adalah fenomena dapat dicatat dan perilaku dapat diketahui dengan jelas. Tugas pencatat (pengamat) yaitu memberi tanda pada kategori di mana perilaku tersebut cocok ditempatkan dalam sel tertentu, alat yang digunakan untuk memberi tanda bisa dengan pensil maupun bolpoin. Pencatat (pengamat) memberikan tanda cek berupa tanda silang, coretan berbentuk huruf $(\sqrt{ })$ atau dilingkari dan bentuk lain yang ditetapkan secara pasti dan digunakan secara seragam dan konsekuen selama pengamatan dilakukan (Nazir, 2011, p.186).

\section{Rekonstruksi Instrumen Observasi untuk Para Ahli Materi}

Berikut ini dilakukan rekonstruksi instrumen observasi berupa daftar cek. Unsurunsur yang disusun dalam daftar cek adalah unsur-unsur yang berkaitan dengan (a) keamanan modifikasi, (b) dapat digunakan untuk massal, (c) murah, (d) menyenangkan, (e) bermanfaat. Dalam penyusunan instrumen observasi, terdapat perbedaan antara instrumen observasi untuk pakar sepakbola, kesehatan dan guru olahraga dikarenakan perbedaan latar belakang dari ketiganya.

Tabel 4. Kisi-kisi Observasi untuk Para Pakar

Sepakbola Terhadap Modifikasi Permainan

Sepakbola bagi Siswa SMA Penderita Asma

\begin{tabular}{clc}
\hline No & \multicolumn{1}{c}{ Klasifikasi } & Item Nomor \\
\hline 1. & $\begin{array}{l}\text { Kemudahan dalam melaku- } \\
\text { kan permainan asmaball }\end{array}$ & 1 \\
2. & $\begin{array}{l}\text { Kesesuaian peraturan per- } \\
\text { mainan dengan peraturan } \\
\text { sepakbola }\end{array}$ & $2,3,10$ \\
3. $\begin{array}{l}\text { Murah dalam biaya dan bisa } \\
\text { digunakan untuk massal }\end{array}$ & 4,5 \\
4. $\quad \begin{array}{l}\text { Keamanan dari peralatan } \\
\text { permainan asmaball ini }\end{array}$ & 6 \\
5. $\begin{array}{l}\text { Permainan yang bersifat me- } \\
\text { narik dan bersifat refreshing }\end{array}$ & 7 \\
6. $\begin{array}{l}\text { Areal lapangan yang me- } \\
\text { mungkinkan untuk diguna- } \\
\text { kan }\end{array}$ & 9 \\
7. Waktu permainan bersifat \\
memungkinkan masuk toler- \\
ansi intermitten
\end{tabular}


Tabel 5. Kisi-kisi Observasi untuk Para Pakar

Kesehatan Terhadap Modifikasi Permainan

Sepakbola bagi Siswa SMA Penderita Asma

\begin{tabular}{|c|c|c|}
\hline No & Klasifikasi & Item Nomor \\
\hline 1. & $\begin{array}{l}\text { Kemudahan dalam melaku- } \\
\text { kan permainan asmaball ba- } \\
\text { gi penderita asma }\end{array}$ & 1 \\
\hline 2. & $\begin{array}{l}\text { Modifikasi peraturan mem- } \\
\text { beri toleransi bagi penderita } \\
\text { asma }\end{array}$ & 3,9 \\
\hline 3. & $\begin{array}{l}\text { Toleransi waktu permainan } \\
\text { masuk ke dalam sifat inter- } \\
\text { mitten }\end{array}$ & 8 \\
\hline 4. & $\begin{array}{l}\text { Murah dalam biaya dan bisa } \\
\text { digunakan untuk massal }\end{array}$ & 4 \\
\hline 5. & $\begin{array}{l}\text { Permainan yang bersifat me- } \\
\text { narik dan bersifat refreshing }\end{array}$ & 7 \\
\hline 6. & $\begin{array}{l}\text { Keamanan peralatan untuk } \\
\text { permainan asmaball }\end{array}$ & 6 \\
\hline 7. & $\begin{array}{l}\text { Kemudahan dalam menda- } \\
\text { patkan peralatan permainan }\end{array}$ & 5 \\
\hline 8. & $\begin{array}{l}\text { Peraturan permainan dapat } \\
\text { dilaksanakan oleh penderita } \\
\text { asma }\end{array}$ & 2 \\
\hline 9 & $\begin{array}{l}\text { Permainan sepakbola menja- } \\
\text { di alternatif bagi penderita } \\
\text { asma }\end{array}$ & 10 \\
\hline
\end{tabular}

Tabel 6. Kisi-kisi Observasi untuk Guru

Olahraga Terhadap Modifikasi Permainan

Sepakbola bagi Siswa SMA Penderita Asma

\begin{tabular}{clc}
\hline No & \multicolumn{1}{c}{ Klasifikasi } & Item Nomor \\
\hline 1. & $\begin{array}{l}\text { Kemudahan dalam melaku- } \\
\text { kan permainan asmaball ba- } \\
\text { gi penderita asma }\end{array}$ & 1 \\
2. & $\begin{array}{l}\text { Toleransi waktu permainan } \\
\text { masuk ke dalam sifat inter- } \\
\text { mitten }\end{array}$ & 8 \\
3. & $\begin{array}{l}\text { Murah dalam biaya dan bisa } \\
\text { digunakan untuk massal }\end{array}$ & 4 \\
4. & $\begin{array}{l}\text { Permainan yang bersifat me- } \\
\text { narik dan bersifat refreshing }\end{array}$ & 7 \\
5. & $\begin{array}{l}\text { Keamanan peralatan untuk } \\
\text { permainan asmaball }\end{array}$ \\
6. $\begin{array}{l}\text { Kemudahan dalam menda- } \\
\text { patkan peralatan permainan }\end{array}$ & 5 \\
7. $\begin{array}{l}\text { Peraturan permainan dapat } \\
\text { dilaksanakan oleh penderita } \\
\text { asma dan tidak menyimpang } \\
\text { dari aturan sepakbola }\end{array}$ & 2,3 \\
8ermainan sepakbola bisa \\
dimainkan di lingkungan se- \\
kolahan
\end{tabular}

\section{Rekontruksi Instrumen untuk Mengobservasi Keefektifan Modifikasi Permainan Sepakbola bagi Penderita Asma.}

Rekontruksi instrumen untuk mengobservasi keefektifan modifikasi permainan sepakbola memiliki arti penting, karena untuk mengetahui apakah modifikasi permaianan sepakbola yang telah dibuat efektif atau tidak untuk siswa yang menderita asma. Untuk intrumen keefektifan modifikasi ini diisi para ahli dan oleh siswa yang menderita asma atau subjek penelitian, dikarenakan ahli akan menilai seberapa efektif permainan lewat rekaman video sedangkan siswa yang asma adalah orang yang melakukan langsung sendiri modifikasi permainan sepakbola bagi penderita asma, sehingga dapat langsung merasakan sendiri kemanfaatannya bagi siswa. Berikut pemaparannya kisi-kisi instrumen:

Tabel 7. Kisi-kisi Instrumen untuk Mengobservasi Keefektifan Modifikasi Permainan Sepakbola bagi Siswa SMA Penderita Asma oleh Siswa

\begin{tabular}{|c|c|c|}
\hline No & Unsur-unsur Observasi & Item Nomor \\
\hline 1 & $\begin{array}{l}\text { Modifikasi permainan ini ti- } \\
\text { dak menyebabkan batuk dan } \\
\text { sesak nafas }\end{array}$ & 1 \\
\hline 2 & $\begin{array}{l}\text { Modifikasi permainan ini ti- } \\
\text { dak menyebabkan lemas dan } \\
\text { pusing }\end{array}$ & 2 \\
\hline 3 & $\begin{array}{l}\text { Modifikasi ini memotivasi } \\
\text { untuk berolahrga }\end{array}$ & 3 \\
\hline 4 & $\begin{array}{l}\text { Jumlah pemain membantu } \\
\text { dalam bergerak }\end{array}$ & 4 \\
\hline 5 & $\begin{array}{l}\text { Peraturan mudah dipahami } \\
\text { pemain }\end{array}$ & 5 \\
\hline 6 & $\begin{array}{l}\text { Peraturan membuat pemain } \\
\text { menikmati permainan }\end{array}$ & 6 \\
\hline 7 & $\begin{array}{l}\text { Permainan sebagai alterna- } \\
\text { tive olahraga untuk asma }\end{array}$ & 7 \\
\hline 8 & $\begin{array}{l}\text { Modifikasi permainan tidak } \\
\text { seberat sepakbola konven- } \\
\text { sional }\end{array}$ & 8 \\
\hline 9 & $\begin{array}{l}\text { Gawang memudahkan untuk } \\
\text { mencetak gol }\end{array}$ & 9 \\
\hline 10 & $\begin{array}{l}\text { Peralatan mudah dipersiap- } \\
\text { kan dan tidak berbahaya }\end{array}$ & 10 \\
\hline
\end{tabular}


Tabel 8. Kisi-kisi Instrumen untuk Mengobservasi Keefektifan Modifikasi Permainan Sepakbola oleh Para Ahli Materi

\begin{tabular}{clc}
\hline No & \multicolumn{1}{c}{ Unsur-unsur Observasi } & Item Nomor \\
\hline 1 & $\begin{array}{l}\text { Dengan modifikasi permainan } \\
\text { sepakbola membantu mening- } \\
\text { katkan kebugaran jasmani }\end{array}$ & 1 \\
2 & $\begin{array}{l}\text { Modifikasi permainan sepak- } \\
\text { bola bisa diterapkan di }\end{array}$ & 2 \\
& $\begin{array}{l}\text { sekolah } \\
3\end{array}$ & \\
4 & $\begin{array}{l}\text { Modifikasi permainan tidak } \\
\text { Modifikasi permainan sebagai } \\
\text { alternatif permainan sepak- } \\
\text { bola bagi penderita asma } \\
\text { Modifikasi permainan bisa } \\
\text { memotivasi penderita asma } \\
\text { Modifikasi permainan bisa } \\
\text { dimainkan oleh massal dan } \\
\text { refreshing } \\
\text { Toleransi waktu permainan } \\
\text { aman untuk penderita asma } \\
\text { karena masuk dalam toleransi } \\
\text { intermitten }\end{array}$ \\
\hline
\end{tabular}

Instrumen untuk Mengobservasi Guru Pelaku Uji Coba

Hal lain yang perlu diobservasi adalah mengenai guru pelaku uji coba. Proses observasi dapat digunakan sebagai alat evaluasi kinerja guru dalam menyampaikan modifikasi pemainan sepakbola serta memberi umpan balik bagi peneliti dalam menjelaskan modifikasi permainan pada guru. Misalnya, guru dalam menyampaikan permainan sepakbola belum sesuai dengan modifikasi permainan sepakbola yang disusun. Hal tersebut dapat terjadi karena peneliti kurang jelas dalam memberikan penjelasan mengenai modifikasi permainan pada guru yang bersangkutan. Di sisi lain, boleh jadi modifikasi permainan tidak berlangsung sesuai harapan bukan karena kekurangan peneliti dalam menjelaskan, namun dikarenakan guru kurang jelas dalam memberi arahan ataupun kurang dalam memotivasi siswa. Hasil observasi terhadap kinerja guru berguna untuk memberi umpan balik bagi guru dan peneliti. Adapun kisi-kisi untuk mengobservasi guru pelaksana uji coba dipaparkan pada tabel berikut ini
Tabel 9. Kisi-kisi Untuk Mengobservasi Guru yang Melakukan Uji Coba

\begin{tabular}{clc}
\hline No & \multicolumn{1}{c}{$\begin{array}{c}\text { Unsur-unsur Untuk } \\
\text { Mengobservasi Guru }\end{array}$} & Item Nomor \\
\hline 1. & $\begin{array}{l}\text { Guru cukup jelas dalam mem- } \\
\text { berikan petunjuk kegiatan }\end{array}$ & 1 \\
2. & $\begin{array}{l}\text { Guru cukup menguasai per- } \\
\text { mainan }\end{array}$ & 2 \\
3. & $\begin{array}{l}\text { Guru dapat menguasai siswa } \\
\text { selama kegiatan berlangsung }\end{array}$ & 3 \\
4. $\quad \begin{array}{l}\text { Guru dapat memotivasi siswa } \\
\text { untuk melakukan kegiatan }\end{array}$ & 4 \\
5. $\begin{array}{l}\text { Guru melaksanakan kegiatan } \\
\text { sesuai dengan modifikasi per- } \\
\text { mainan }\end{array}$ & 5 \\
\hline
\end{tabular}

\section{Instrumen Penilaian Siswa}

Instrumen penilaian siswa adalah format penilaian yang digunakan guru untuk menilai kinerja siswa saat melaksanakan gerakan dalam modifikasi permainan sepakbola bagi penderita asma. Format penilaian akan memudahkan guru dalam mengevaluasi penampilan siswa.

Teknik Analisis Data

Teknik analisis data yang dilakukan dalam penelitian ini yaitu analisis deskriptif kuantitatif dan analisis deskriptif kualitatif. Analisis deskriptif kuantitatif dilakukan untuk menganalisis data-data berikut: (1) data skala nilai hasil penilaian para ahli materi terhadap draf modifikasi permainan sepakbola bagi penderita asma sebelum pelaksanaan uji coba di lapangan, (2) data hasil observasi para ahli materi terhadap modifikasi permainan sepakbola bagi penderita asma, (3) data hasil observasi para ahli materi terhadap keefektifan modifikasi permainan sepakbola dan (4) data hasil observasi para siswa penderita asma terhadap keefektifan modifikasi permainan sepakbola. Sementara analisis deskriptif kualitatif dilakukan terhadap: (1) data hasil wawancara dengan siswa penderita asma dan guru olahraga (2) data kekurangan dan masukan terhadap modifikasi permainan sepakbola bagi penderita asma baik sebelum uji coba maupun setelah uji coba di lapangan.

Draf awal modifikasi permainan sepakbola asma dianggap layak untuk diujicobakan dalam skala kecil apabila para ahli materi telah memberi validasi dan menyatakan bahwa semua item klasifikasi dalam skala nilai dinilai "Setuju dan Tidak Setuju" dengan cara memberi tanda centang $(\sqrt{ })$ pada kolom setuju dan tidak setuju. Dalam hal ini terdapat 2 jenis penilaian, yaitu 
hasil penilaian "Ya" diberi skor (1) dan "Tidak Setuju " diberi skor (0). Jika terdapat ahli materi yang berpendapat bahwa item klasifikasi tidak setuju (0), maka dilakukan pengkajian ulang terhadap model senam Si Buyung yang dapat ditindaklanjuti dengan proses revisi.

Untuk data hasil observasi para ahli materi terhadap modifikasi permainan sepakbola bagi penderita asma, keefektifan modifikasi permainan menggunakan dua jenis penilaian. Untuk observasi draf dan keefektifan modifikasi permainan oleh ahli materi menggunakan skala 2 yaitu "Ya" mendapat nilai satu (1) dan "Tidak" mendapat nilai nol (0). Sedangkan untuk siswa menggunakan skala 4 yaitu "Sangat Setuju (SS)" mendapat skor (4), "Setuju (S)" mendapat skor (3), "Tidak Setuju (ST)" mendapat skor (2), "Sangat Tidak Setuju (STS)" mendapat skor 1. Hasil penilaian terhadap itemitem observasi dijumlahkan, lalu total nilainya dikonversikan untuk mengetahui kategorinya. Pengkonversian nilai dilakukan dengan mengikuti standar Penilaian Acuan Patokan (PAP). Saifudin (2005, p.109) menyatakan dalam menginterpretasikan skor mentah menjadi nilai dengan menggunakan pendekatan PAP, terlebih dahulu ditentukan kriteria nilai dan batas-batasnya, yang akan dipaparkan pada tabel di bawah ini.

Tabel 10. Pedoman Konversi Nilai (Saifudin, 2005, p.109)

\begin{tabular}{ccc}
\hline Formula & Batasan & Kategori \\
\hline$X<(\mu-1,0 \sigma)$ & $X<16,67$ & Kurang \\
$(\mu-1,0 \sigma) \leq X<$ & $16,67 \leq X<$ & Cukup \\
$(\mu+1,0 \sigma)$ & 33,33 & \\
$(\mu+1,0 \sigma) \leq X$ & $33,33 \leq X$ & Baik \\
\hline
\end{tabular}

\section{Hasil Penelitian dan Pembahasan}

Data Validasi Ahli

Setelah draf modifikasi permainan sepakbola dibuat maka tahap selanjutnya adalah melakukan validasi dari draf yang dilakukan para ahli yaitu (1) ahli sepakbola Drs. Herwin, M.Pd. (2) ahli kesehatan yaitu dr. Novita Intan Arovah, MPH. (3) Guru olahraga SMA De Britto yaitu $\mathrm{CH}$. Danang Wahyu, S. Pd. Pada tahap validasi ini para ahli melakukan penilaian terhadap draf dan memberi masukan-masukan sehingga draf layak untuk dilakukan uji coba.

\section{Data Uji Coba Lapangan Skala Kecil}

Setelah mendapat validasi para ahli materi terhadap draf awal modifikasi permainan sepakbola bagi penderita asma, peneliti melaku- kan uji coba lapangan skala kecil di lapangan futsal SMA Kolese De Britto. Uji coba dilakukan pada hari Rabu tanggal 13 Mei 2013 dengan subjek berjumlah 13 siswa yang memiliki asma ringan. Pada saat melakukan uji coba skala kecil siswa tidak mengalami kekambuhan asmanya. Dari pelaksanaan uji coba skala kecil, didapatkan data dari ahli materi (pakar sepakbola, pakar kesehatan dan guru olahraga), meliputi: (1) data hasil observasi, (2) data hasil observasi keefektifan modifikasi sepakbola, (3) data observasi keefektifan dari siswa sebagai pengguna, (4) data kekurangan modifikasi permainan sepakbola, dan (5) data masukan terhadap modifikasi sepakbola untuk asma. Datadata tersebut dipaparkan berikut ini.

\section{Data Observasi Model}

Tabel di atas menunjukan penilaian para ahli materi terhadap draf modifikasi permainan sepakbola bagi siswa SMA penderita asma ada subjek (0\%) yang memandang kurang, tidak ada subjek $(0 \%)$ yang memandang cukup, dan 3 responden (100\%) memandang baik. Total nilai pakar sepakbola adalah 7 terletak pada interval 4,67 $\leq X$, total nilai pakar kesehatan adalah 7 terletak pada interval $4,67 \leq X$, dan total nilai guru olahraga 7 terletak $4,67 \leq \mathrm{X}$, maka pandangan ahli materi terhadap modifikasi permainan sepakbola bagi siswa SMA penderita asma memandang baik.

\section{Data Observasi Keefektifan Model}

Penilaian ahli materi terhadap guru pelaku uji coba, tidak ada subjek $(0 \%)$ yang kategori kurang, tidak ada subjek (0\%) yang kategori cukup, dan tiga responden $(100,00 \%)$ kategori baik. Total nilai para ahli semuanya sama yaitu sebesar 5 terletak pada interval $3,33 \leq \mathrm{X}$, maka penilaian para ahli materi terhadap hasil observasi guru yang melakukan uji coba mengkategorikan baik.

\section{Data Kekurangan dan Masukan Ahli Materi}

Adapun masukan dari pakar sepakbola yang pertama adalah jumlah pemain tolong diperhatikan lagi karena masih terlalu banyak gerakan anak tidak bebas sehingga anak tidak bisa memenuhi waktu anaeroik seperti yang diharapkan dari waktu intermitten yaitu diharapkan anaerobic 2 menit. Masukan yang kedua pada saat bola throw in dibebaskan waktunya karena permainan ini tidak untuk kompetisi sehingga pemain tidak terburu-buru. Masukan ketiga adalah waktu permainan asmaball adalah 
waktu bersih yang artinya waktu berhenti pada saat bola keluar lapangan sehingga waktu permainan tidak terbuang untuk bola keluar dan pelanggaran-pelanggaran. Masukan keempat adalah jarak areal penalti masih terlalu dekat yaitu hanya 2 meter sehingga bisa mengganggu pemain bertahan untuk melakukan goal kick bisa di perluas lagi areal penalti sehingga pemain penyerang akan ada jarak dengan pemain yang melakukan goal kick. Masukan yang kelima adalah peraturan tentang akumulasi pelanggaran dari setiap pemain masih terlalu banyak dalam satu babak, bisa dilihat dalam satu babak belum tentu terjadi pelanggaran sebanyak itu, untuk itu diperhatikan jumlah akumulasinya.

Masukan dari pakar kesehatan sebagai berikut yang pertama adalah jumlah pemain masih terlalu banyak maka dari itu jumlah pemain harus dikurangi sehingga diharapkan setiap pemain bisa melakukan gerakan bebas dan setiap pemain diharapkan bisa masuk ke kategori waktu intermitten seperti yang direkomendasikan untuk penderita asma yaitu aerobic 4 menit anaerobic 2 menit dan 4 menit aerobic. Masukan yang kedua adalah pemain disarankan untuk memakai sepatu ket karena di areal lapangan yang berlantai akan berbahaya untuk pemain bisa membuat lecet kaki maka dari itu disarankan untuk memakai sepatu ket.

Masukan dari guru olahraga sama seperti dengan pakar kesehatan yaitu disarankan untuk pemain memakai sepatu ket. Masukan dari siswa sebagai pelaku uji coba yaitu masukan yang pertama adalah jumlah pemain yang masih terlalu banyak karena gerakan pemain masih tidak bebas karena luas areal lapangan menjadi sempit karena pemain menumpuk. Masukan yang kedua adalah jarak areal penalti masih terlalu kecil sehingga pemain lawan terlalu dekat dengan pemain yang sedang melakukan goal kick. Menyikapi kekurangan dan masukan dari para ahli materi terhadap modifikasi permainan sepakbola bagi siswa SMA penderita asma, peneliti melakukan dua hal, yaitu: (1) melakukan perbaikan terhadap kekurangan dengan menerima masukan ahli materi disertai alasannya, dan (2) tidak mengubah modifikasi dengan tidak menggunakan masukan ahli disertai alasannya.

\section{Data Kuesioner Siswa}

Data kuesioner untuk siswa menunjukkan bahwa respon dari peserta didik yang menjadi sampel pada uji coba skala kecil, secara umum memberikan respon yang positif terhadap model pembelajaran bolavoli. Peserta didik merasa senang melakukan permainan yang diajarkan dan ingin melakukannya kembali di luar jam sekolah atau di rumah.

\section{Data Uji Coba Lapangan Skala Besar}

Penilaian para ahli materi terhadap draf modifikasi permainan sepakbola bagi penderita asma ada subjek (0\%) yang memandang kurang, tidak ada subjek $(0 \%)$ yang memandang cukup, dan 3 responden (100\%) memandang baik. Total nilai pakar sepakbola adalah 10 terletak pada interval $6,67 \leq X$, total nilai pakar kesehatan adalah 10 terletak pada interval 6,67 $\leq X$, dan total nilai guru olahraga 10 terletak $6,67 \leq \mathrm{X}$, maka pandangan ahli materi terhadap modifikasi permainan sepakbola bagi penderita asma memandang baik.

\section{Data Observasi Model}

Penilaian para ahli materi terhadap draf modifikasi permainan sepakbola bagi penderita asma ada subjek (0\%) yang memandang kurang, tidak ada subjek $(0 \%)$ yang memandang cukup, dan 3 responden $(100 \%)$ memandang baik. Total nilai pakar sepakbola adalah 10 terletak pada interval $6,67 \leq X$, total nilai pakar kesehatan adalah 10 terletak pada interval $6,67 \leq X$, dan total nilai guru olahraga 10 terletak $6,67 \leq X$, maka pandangan ahli materi terfadap modifikasi permainan sepakbola bagi penderita asma memandang baik.

\section{Data Observasi Keefektifan Model}

Penilaian para ahli materi terhadap draf modifikasi permainan sepakbola bagi siswa SMA penderita asma ada subjek $(0 \%)$ yang memandang kurang, tidak ada subjek $(0 \%)$ yang memandang cukup, dan 4 responden (100\%) memandang baik. Total nilai pakar sepakbola adalah 7 terletak pada interval $4,67 \leq \mathrm{X}$, total nilai pakar kesehatan adalah 7 terletak pada interval $4,67 \leq X$, dan total nilai guru olahraga 7 terletak 4, $67 \leq X$, maka pandangan ahli materi terhadap modifikasi permainan sepakbola bagi siswa SMA penderita asma memandang baik.

\section{Data Kekurangan dan Masukan Ahli Materi}

Berdasarkan dari penilaian ahli materi terhadap instrumen observasi, para ahli materi sependapat bahwa modifikasi permainan sepakbola sudah masuk dalam kategori baik sehingga bisa digunakan untuk alternatif olahraga bagi penderita asma dan bisa diterapkan di sekolah. 
Siswa sebagai pelaku dalam uji coba mayoritas siswa menyatakan bahwa modifikasi permainan sepakbola bagi penderita asma masuk dalam kategori baik.

Ahli sepakbola dan guru olahraga sependapat menilai tidak ada kekurangan dan masukan dalam modifikasi permainan sepakbola bagi siswa SMA penderita asma. Sedangkan pakar kesehatan memberi masukan yang pertama dengan selalu menyediakan minuman dan masukan yang kedua kalau perlu minum obat asma sebelum berolahraga sehingga pada saat bermain tidak kambuh dan selalu menyiapkan inhaler untuk berjaga-jaga kalau kambuh asma langsung digunakan.

Penyempurnaan pada uji skala besar sangat maksimal berdasarkan banyaknya kekurangan dan masukan-masukan dari uji skala kecil. Bentuk kekurangan dan masukan dari para ahli benar-benar diterapkan dalam uji skala besar sehingga hasil yang diinginkan dari para ahli sepakbola dan guru olahraga dapat terpenuhi. Para ahli materi yang terdiri dari ahli sepakbola, ahli kesehatan, guru olahraga dan siswa sebagi pelaku setuju dengan produk modifikasi permainan sepakbola bagi siswa SMA penderita asma untuk dijadikan produk final.

\section{Data Kuesioner Siswa}

Data kuesioner untuk siswa, menunjukkan bahwa respon dari peserta didik yang menjadi sampel pada uji coba skala besar, secara umum memberikan respon yang positif terhadap model pembelajaran bolavoli. Peserta didik merasa senang melakukan permainan yang diajarkan dan ingin melakukannya kembali di luar jam sekolah atau di rumah. Setelah mendapat penilaian dan masukan, baik dari para ahli materi maupun guru pendidikan jasmani sekolah dasar pelaku uji coba kemudian dilakukan proses-proses revisi terhadap draf model pembelajaran Bolavoli yang dikembangkan. Proses revisi terhadap produk model pembelajaran bolavoli ini terdiri dari: (1) revisi draf produk awal, (2) revisi produk uji coba skala kecil, dan (3) revisi produk uji coba skala besar. Akhirnya dihasilkan model pembelajaran bolavoli untuk anak sekolah dasar kelas atas, yang terdiri dari empat model permainan (masing-masing meliputi beberapa bentuk variasi gerak), yaitu: (1) pembelajaran teknik dasar passing bawah, (2) pembelajaran teknik dasar passing atas, (3) pembelajar- an teknik dasar servis bawah, dan (4) pembelajaran teknik dasar servis atas, yang disusun dalam bentuk buku panduan dan layak untuk digunakan.

\section{Hasil Modifikasi Permainan Sepakbola}

\section{Pemanasan dan Pendinginan}

Pemanasan sederhana seperti pemanasan pada permainan sepakbola intinya untuk mempersiapkan otot untuk siap melakukan latihan. Gerakannya mulai dari kepala sampai ke kaki, bisa menggunakan gerakan senam Samba.

Pendinginan sama seperti pendinginan seperti biasanya yang intinya mengembalikan struktur otot setelah melakukan latihan.

\section{Modifikasi Permainan Sepakbola Asmaball}

Permainan sepakbola asmaball ini memodifikasi lapangan sepakbola, jumlah gawang dan ukuran, jumlah pemain, dan peraturan permainan asmaball.

- Panjang lapangan $\quad: 25$ meter

- Lebar lapangan $\quad: 15$ meter

- Daerah penalti : jarak 5 meter

- Daerah lingkaran tengah : 3 meter

- Alasan dari penentuan lapangan:

Peneliti menentukan panjang dan lebar lapangan berdasarkan perbandingan dari seperempat lapangan standar.

Berdasarkan uji lapangan, survey dari peneliti ketiga kabupaten-kota di Yogyakarta yaitu Kabupaten Sleman, Daerah Kota Yogyakarta, dan Kabupaten Bantul dengan 5 tempat yang dikunjungi di antaranya tempat pendidikan ataupun di pemukiman masyarakat adanya lapangan atau tanah kosong dengan ukuran yang memungkinkan dengan ukuran 25 meter dan 15 meter, dikarenakan untuk luas lahan yang masih kosong sudah sangat kesulitan.

Kenyataannya bahwa penderita asma adalah orang yang memiliki ganguan pada sistem pernafasannya berbeda dengan manusia pada umumnya jadi akan kesulitan jika harus bermain dengan lapangan konvensional atau lapangan standar, oleh karena itu untuk meminimalisir kemungkinan kambuhnya asma diperkecil areal lapangan.

Jumlah gawang: 4 dengan ukuran panjang 1 meter dan lebar $70 \mathrm{~cm}$ dan terbuat dari pralon. Berikut adalah bentuk lapangan dan ukurannya. 


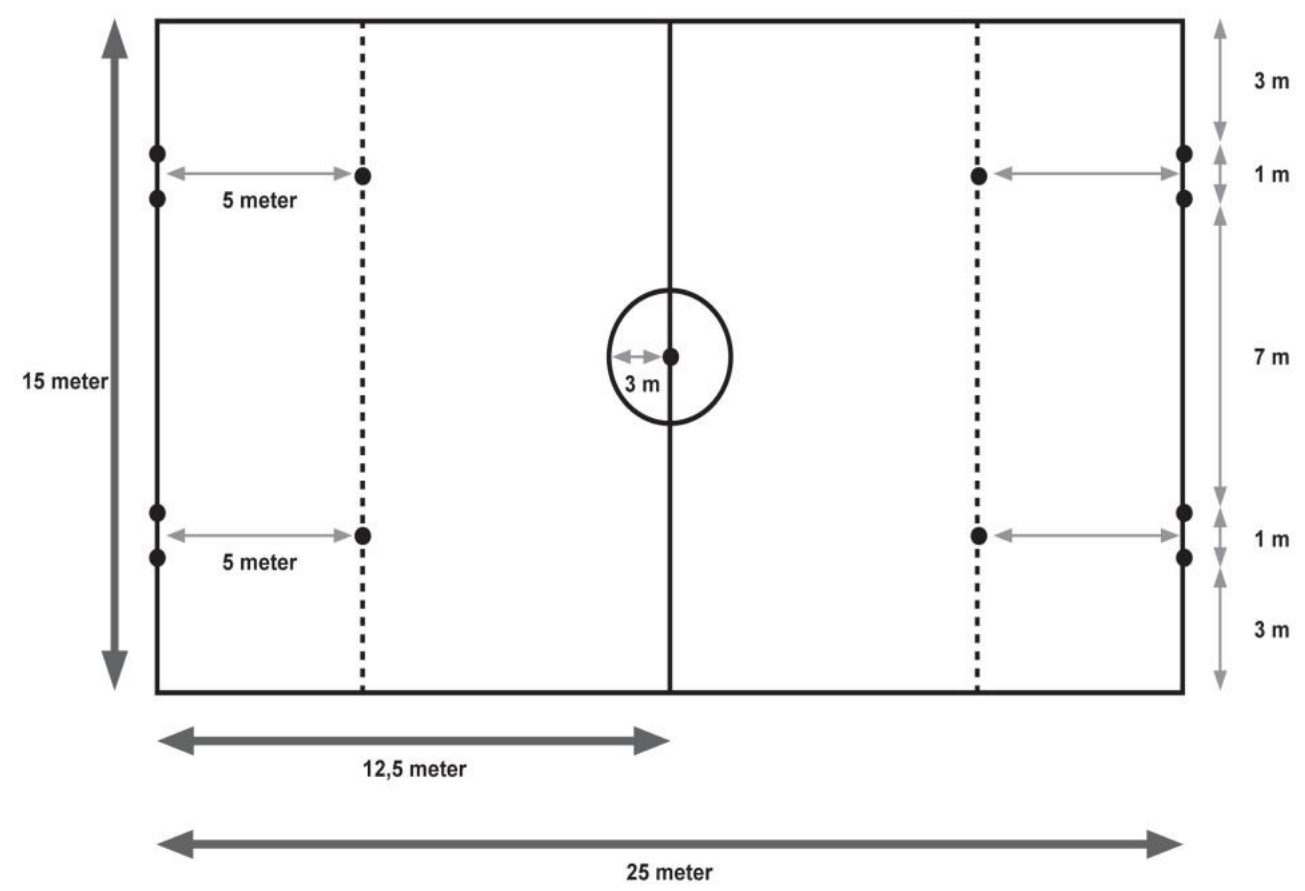

\section{Lapangan Asmaball}

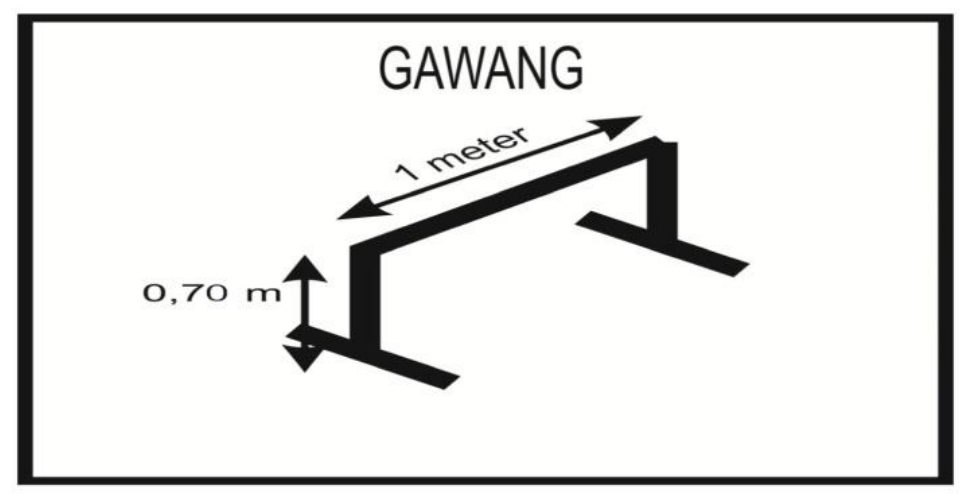

Alasan penentuan ukuran gawang dan jumlah gawang: (1) Mengkondisikan pemain agar tetap harus berpikir dan mengambil keputusan dalam bermain dengan memilih mencetak gol pada gawang mana, ini dikarenakan penderita asma kambuh karena mengalami kekurangan $\mathrm{O}_{2}$ pada sitem pernafasan sehingga suplai $\mathrm{O}_{2}$ keseluruh tubuh akan terganggu termasuk suplai $\mathrm{O}_{2}$ pada otak untuk itu dalam dirangsang dan dikondisikan dalam kekurangan oksigen tetap harus berpikir dan mengambil keputusan sehingga dengan gawang 4 diharapkan penderita asma dirangsang dan dikondisikan untuk tetap berpikir; (2) Lebar gawang satu meter karena menyesuaikan lebar lapangan, (a) Dengan lebar gawang 1 meter dan tinggi $70 \mathrm{~cm}$ akan membantu pemain dalam mencetak gol tetapi juga tidak terlalu mudah karena akan ada rintangan dari pemain lawan, (b) Garis lapangan: $8 \mathrm{~cm}$, (c) Waktu permainan: 2 x 10 menit dengan waktu istirahat 5 menit.

Alasannya: olahraga yang disarankan adalah olahraga yang bersifat intermittent, yang artinya olahraga berselang seling antara aerobik dan anaerobic. Dengan waktu 4 menit aerobik yaitu untuk melatih kekuatan otot-otot pernafasan dan 2 menit anaerobic yang bertujuan untuk mengadaptasi keadaan kekurangan oksigen dalam organ pernafasan.

Bola yang digunakan: Bola ukuran 4 atau bola futsal. Peraturan permainan dari Asmaball ini yaitu: (1) Permainan dimainkan di lantai atau rumput sintetis, kalau terpaksa bisa di tanah tetapi harus disiram sehingga tidak berdebu, (2) Pemain berjumlah 5 pemain tanpa penjaga gawang dan pergantian bebas, (3) Pe- 
main boleh mencetak gol di dua gawang lawan, (4) Semua pemain penyerang harus keluar dari daerah garis 5 meter gawangnya pada saat menyerang, (5) Memulai permainan dari garis tengah Kick off dari tengah dilakukan dua kali sentuh, (6) Memulai permainan dari out dilakukan seperti futsal dengan bola diletakkan di garis atau belakang garis dengan waktu bebas, (7) Setiap terjadi hands ball dilakukan tendangan ke arah gawang tanpa ada yang menghalang$i$, pemain boleh langsung menendang bola masuk ke gawang atau passing ke teman satu tim, (8) Jika terjadi pelanggaran berat hukumannya sama seperti handsball, (9) Jika terjadi pelanggaran ringan dimulai dari luar, kalau pelanggaran 3 kali dalam satu babak akan dilakukan penalti, (10) Jarak penjaga pada saat goal kick adalah di luar kotak penalti yaitu 5 meter dari garis penalti, (11) Jarak pemain lawan pada throw in dan saat tendangan sudut 2 meter, (12) Disarankan menggunakan sepatu ket, (13) Untuk membedakan anggota sebaiknya dengan memakai rompi atau seragam yang berbeda sehingga sebagai pembeda, (14) Jangan lupa menyediakan inhaler atau meminum obat asma sebelum bemain, (15) Selalu menyediakan air minum sehingga tidak dehidrasi, (16) Permainan tidak untuk prestasi melainkan sebagai sarana untuk rekreasi.

\section{Simpulan dan Saran}

Simpulan

Hasil penilaian para ahli materi terhadap modifikasi permainan sepakbola bagi siswa SMA penderita asma, disimpulkan bahwa modifikasi permainan sepakbola yang disusun sangat baik dan efektif dalam menjadi alternative bagi penderita asma untuk berolahraga terutama penderita asma yang tertarik untuk bermain sepakbola, dari penilaian para ahli meteri dapat disimpulkan bahwa modifikasi permainan sepakbola yang dikembangkan layak digunakan untuk pembelajaran pada siswa SMA. Produk dari penelitian pengembangan yaitu buku dengan judul ASMABALL Modifikasi permainan sepakbola bagi siswa SMA penderita asma.

Di dalam buku modifikasi permainan sepakbola bagi siswa SMA penderita asma (asmaball) dalam Bab 1 terdapat penjelasan tentang seputar asma dan jenis-jenis tingkatan asma, Bab 2 terdapat modifikasi permainan asmaball mengenai ukuran lapangan, ukuran gawang, jumlah pemain dan peraturan permainan asmaball, Bab 3 atlet profesional penderita asma.

Saran

Saran pemanfaatan berdasarkan penelitian pengembangan yaitu agar modifikasi permainan sepakbola bagi siswa SMA penderita asma yang dikembangkan dapat digunakan guru sebagai salah satu alternatif bagi pembelajaran di SMA terutama bagi siswa yang menderita asma yang tertarik ingin bermain sepakbola dan bisa digunakan para siswa yang penderita asma di lingkungan masyarakat luas.

Diseminasi hasil penelitian ini dapat dilakukan melalui seminar-seminar, dan dalam bentuk pembuatan artikel, atau dapat juga dilakukan melalui penelitian tindakan kelas ataupun eksperimen dengan melibatkan guru SMA untuk mengetahui efek nyata dari produk permainan sepakbola bagi penderita asma.

Untuk pengembangan produk lebih lanjut perlu dilakukan penelitian yang melibatkan subjek coba lebih besar dan cakupan tempat uji coba yang lebih luas. Di sisi lain, dapat juga dilakukan penelitian serupa dengan sasaran subjek siswa siswi SMA dan siswa SMP.

\section{Daftar Pustaka}

Azwar, Saifudin. (2005). Penyusunan skala psikologi. Yogyakarta: Pustaka Pelajar.

Borg, Walter R. \& Gall. M. D. (1983). Educational research. (an introduction) $4^{\text {th }}$ edition. New York \& London: Longman.

Nelson WE. (1996). Pediatric ilmu kesehatan anak. Terjemahan Wahab S. Vol I: Jakarta. Penerbit EGC.775.

Prasetyo, Budi. (2010). Seputar Massalah Asma. Yogyakarta: Diva Press.

Riduwan. (2007). Skala pengukuran variabelvariabel penelitian. Bandung: Alfabeta. 